
Journal

\title{
Heritage Politics and Policies in Hindu Rashtra
}

Corinne Lefèvre

\section{OpenEdition}

Journals

Electronic version

URL: http://journals.openedition.org/samaj/6728

DOI: $10.4000 /$ samaj.6728

ISSN: 1960-6060

Publisher

Association pour la recherche sur l'Asie du Sud (ARAS)

\section{Electronic reference}

Corinne Lefèvre, « Heritage Politics and Policies in Hindu Rashtra », South Asia Multidisciplinary Academic Journal [Online], 24/25 | 2020, Online since 10 November 2020, connection on 15 December 2020. URL : http://journals.openedition.org/samaj/6728; DOI : https://doi.org/10.4000/samaj.6728

This text was automatically generated on 15 December 2020.

\section{(c) $(1)$}

This work is licensed under a Creative Commons Attribution-NonCommercial-NoDerivatives 4.0 International License. 


\title{
Heritage Politics and Policies in Hindu Rashtra
}

\author{
Corinne Lefèvre
}

I am grateful to Anne Castaing, Caterina Guenzi, NK, and Stéphanie Tawa Lama-Rewal as well as the reviewers for their helpful insights while writing this essay.

\section{Introduction}

1 The year is 2018, twelve months or so before India's general elections and the BJP (Bharatiya Janata Party) leader Narendra Modi's bid for a second term as Prime Minister. On March $13^{\text {th }}$, Dalmia Bharat Limited, an industrial group known primarily for Dalmia Cement, signed a Memorandum of Understanding (MoU) with the Ministry of Tourism, the Ministry of Culture and the Archeological Survey of India (ASI) by which the corporation formally "adopted" the Mughal Red Fort of Delhi under the national "Adopt a Heritage" scheme and committed to provide basic amenities and complete operation and maintenance of this UNESCO World Heritage Site for a minimum duration of five years. ${ }^{1}$ On July $27^{\text {th }}$, the tidy sum of Rupees 1,452 lakhs ${ }^{2}(€$ $1,6 \mathrm{M})$ was sanctioned for the development of a "spiritual circuit" in the state of Uttar Pradesh (UP) under the aegis of another national heritage program known as the "Swadesh Darshan Scheme." 3 Still later that year, on October $16^{\text {th }}$, the BJP government of UP decided to rename the city of Allahabad, Prayagraj, "a twenty-first century Hindutva invention" meant to erase the Mughal past of the city and to restore its primal identity as a major Hindu pilgrimage center. ${ }^{4}$ By the end of that same month, on the $31^{\text {st }}$, Narendra Modi inaugurated with great pomp a colossal statue of Sardar Vallabhbhai Patel (d. 1950), a senior figure of the movement for independence and of the Congress Party whom the Hindu right is currently refurbishing as one of its own, not the least because of the Gujarati origins he shares with N. Modi.

2 Every one of the above-listed public acts obviously relates to the paradigmatic idea of "heritage," a term referring first and foremost to "any relict physical surviving from the past" but that extends to include "all accumulated cultural and artistic productivity 
(...) whether produced in the past or currently" (Ashworth and Tunbridge 1996:1-2, emphasis mine). When considered together, these decisions-whether taken at the federal or state level-reveal the three most salient features of Hindutva heritage politics and policies. First is the state's reluctance to fulfill its traditional role of guardian of the nation's built landscape and the concomitant resort to neo-liberal outsourcing strategies to fill in the gap. Second is a strong sectarian bias at work in the shrinking state-sponsored projects of heritage management and development; a similar prejudice also underpins a large-scale policy of renaming that ultimately aims at emphasizing the Hinduness of India's public space and at expurgating from the latter all material traces related to the pluri-secular presence of non-Hindus (especially Muslims) in the subcontinent. Third is a strong appetite for building new and exorbitant heritage creations, thus recklessly adding to the 3,686 ancient monuments and archaeological sites the state (through the Archeological Survey of India) is increasingly unable to protect.

3 A recent essay by Supriya Gandhi, a historian of the Mughal empire, helps to make sense of the blatant contradictions at work in the Hindu right's thinking about, and management of, Indian material culture, past and present. Reviewing some of the "events" mentioned above, she eloquently writes: "In India, the authoritarian state steadily works to reshape public space by claiming the right to destroy, preserve and build" (Gandhi 2020, emphasis mine). As the present essay will argue, "to preserve, build and destroy" is actually an especially fitting motto to describe the BJP's heritage ideology and practices; it is also a very useful heuristic lens to disentangle the deceptively inconsistent threads adding up to form the new Hindu Rashtra (Hindu nation)'s patrimonial policy and to expose the latter in plain view.

\section{The BJP preservation of India's built heritage: an unsavory blend of sectarian bias and neo-liberalism}

4 The first section of this essay is concerned with Hindutva-inspired policies of heritage conservation and promotion through a discussion of two national programs devised and implemented by the BJP after it won the 2014 general elections: the Swadesh Darshan Scheme (henceforth SDS) and the Adopt a Heritage scheme (henceforth AAH).

The former was officially launched in January 2015 by the Ministry of Tourism under the aegis of the Government of India that also provides most of its funding. Its twofold objective is, in short, to use the tourism sector to boost infrastructure and economic development and "to promote cultural and heritage value of the country" through the creation of fifteen "themed routes" at regional and national levels. ${ }^{5}$ If we are to believe the banner adorning the pages of the official website of the scheme (figure 1) and the communication strategy underlying it, every facet of India's rich built architecture seems at first sight to be eligible for the institution of a themed route. 
Figure 1: The Swadesh Darshan Scheme website banner, ( ) Ministry of Tourism, Government of India

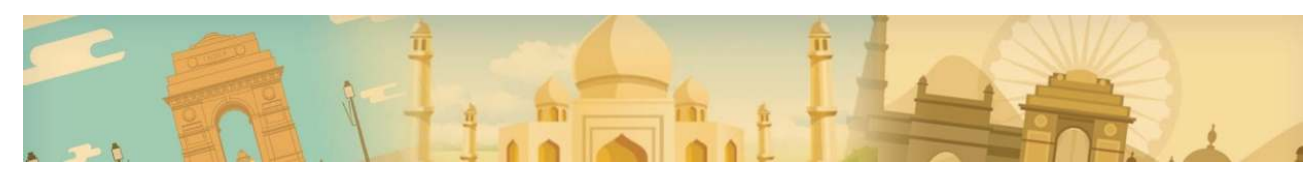

Source: www.swadeshdarshan.gov.in

6 In addition to the world-famous Mughal Taj Mahal situated at the center, it also features the Qutb Minar (to the right), the "victory tower" built by Delhi sultans in the late twelfth-thirteenth century and, on the left, the India Gate of Delhi designed by the British architect Edwin Lutyens (d. 1944), more generally known for his planning of New Delhi. How come, one wonders, the banner gives pride of place to monumental artifacts commissioned by historical Muslim and Christian leaders (to employ the Hindutva idiom)-i.e. members of two non-Hindu minorities that are today daily vilified by the majoritarian Hindu state the Sangh Parivar is building-but includes no material vestige of the relentlessly glorified Hindu past? Can the "Swadesh" (homeland) delineated by an officially BJP-sponsored program possibly diverge from the dogma formulated by V. D. Savarkar (d. 1966), Hindutva's founding father, according to which India is the land of Hindus alone ${ }^{6}$

7 A close look at the list of the themed routes and their itineraries suffices to dispel any doubt, or hope.

Table 1: Overview of the Swadesh Darshan Scheme

\begin{tabular}{|l|l|l|l|}
\hline $\begin{array}{l}\text { Official circuit } \\
\text { name }\end{array}$ & $\begin{array}{l}\text { Number of sub- } \\
\text { circuits }\end{array}$ & $\begin{array}{l}\text { Total of funding } \\
\text { sanctioned } \\
\text { (INR Lakhs) }\end{array}$ & $\begin{array}{l}\text { Chronology of funding } \\
\text { approval }\end{array}$ \\
\hline Buddhist & 6 & 37319,21 & July 2016-June 2018 \\
\hline Coastal & 10 & 77298,54 & March 2015-June 2017 \\
\hline Desert & 1 & 6396,37 & Sept 2015 \\
\hline Eco & 6 & 49050,71 & Sept. 2015-August 2018 \\
\hline Heritage & 10 & 85420,96 & Sept. 2016-August 2018 \\
\hline Himalayan & 7 & 63934,62 & June 2016-March 2017 \\
\hline Krishna & 2 & 18879,69 & September 2016 \\
\hline North-East & 10 & 85609,22 & March 2015-January 2019 \\
\hline Ramayana & 2 & 20275,36 & July 2016-January 2019 2016-Sept. 2017 \\
\hline Rural & 2 & 12502,4 & 067,22 \\
\hline Spiritual & 13 & & June 2017-Sept 2018 \\
\hline
\end{tabular}




\begin{tabular}{|c|c|c|c|}
\hline Sufi & 0 & 0 & $\mathrm{w} / \mathrm{o}$ \\
\hline Tirthankar & 0 & 0 & $\mathrm{w} / \mathrm{o}$ \\
\hline Tribal & 4 & 38011,65 & November 2015-Sept. 2016 \\
\hline Wildlife & 2 & 18790,14 & December 2015 \\
\hline \multicolumn{3}{|l|}{ TOTAL } & \\
\hline 15 & 75 & $\begin{array}{l}589556,09 \\
\text { (INR Crores 5,895.56 / € } \\
678 M)\end{array}$ & \\
\hline
\end{tabular}

Source: www.swadeshdarshan.gov.in

9 As shown by the above table compiled on the basis on the data available on its official website, the SDS does exactly the opposite of what its banners seems to advertise. 30.5\% of the sub-circuits detailed specifically aim at promoting and developing Hindu religious tourism and represent $26 \%$ of the total funding. Although a Sufi themed route is publicized as "one of the key development thrusts of the Ministry of Tourism," the webpage dedicated to it remains significantly empty, ${ }^{7}$ pointing to the lack of any concrete plan of development (the same holds true for the Jain-oriented Tirtankhar circuit). Furthermore, the Spiritual themed route, which one could have expected to include sites of the many spiritual traditions present in India (isn't Sufism a form of spirituality?), blatantly ignores non-Hindu shrines. The tiny number of sites (eight) connected with Islamic traditions that are mentioned in the description of the seventyfive sub-themed routes reflects a similar sectarian bias and disregard for non-Hindu heritage. ${ }^{8}$

10 Nor is the SDS's disregard for non-Hindu heritage an isolated exception where Hindutva-inspired plans for patrimonial conservation and promotion are concerned. Among many other recent examples, only a handful can be mentioned here: the campaign of restoration focusing on sites associated with Hindu mythology conducted in Haryana by Jagmohan, an admittedly complex political figure, during his 2001-2004 mandate as Union Cabinet Minister for Tourism and Culture; ${ }^{9}$ or the Vishwanath Corridor in Varanasi (Kumar 2019), a pet project of N. Modi supported by the UP Chief Minister Yogi Adityanath aiming at facilitating the devotees' access from the Ganga ghats to the Shiva temple through the undiscriminating clearance of the surrounding land (Kumar 2019). These various instances obviously all point in the same direction: the deliberate marginalization of Indian vestiges associated with Islamic and Christian cultures in state-funded heritage conservation and promotion projects. As shown below by the second case study, the BJP's strategy markedly differs when it comes to auctioning pieces of the national patrimony.

11 The administrative tool through which such transactions are currently taking place is called the "Adopt a Heritage" (AAH) scheme. Partaking of the neo-liberal politics that constitute yet another hallmark of Hindutva governance, the program (launched in 2017) invites private and public sector companies and individuals (thence nicknamed Monument Mitras or "friends") to adopt heritage sites and use their CSR (Corporate 
Social Responsibility) funds for the upkeep and maintenance of the latter, thereby substituting for the state in its patrimonial duty. ${ }^{10}$ True, the privatization of heritage conservation has been steadily growing across various nation-states for several decades now: it has become common practice in Europe, as exemplified of late by the controversial "Loto Mission Patrimoine" (akin to the British National Lottery Heritage Fund) sanctioned by the French government of Emmanuel Macron in 2017 and supervised by the notoriously royalist media figure and self-proclaimed historian Stéphane Bern. ${ }^{11}$ There also have been precedents in India, dating back to a time when the BJP was not in power at the federal level (Sankaran 2019:38). However, the recent acceleration of this process through the AAH program takes on an added dimension in the context of Hindu Rashtra building.

Much as in the case of the SDS, a rapid comparative analysis of the AAH's marketing strategy and implementation is especially instructive. As opposed to the SDS banner, the AAH logo (figure 2) seems to negate the very existence of the Indo-Islamic element within Indian heritage.

Figure 2: Official logo of the "Adopt a Heritage" scheme, ( ) Ministry of Tourism, Government of India

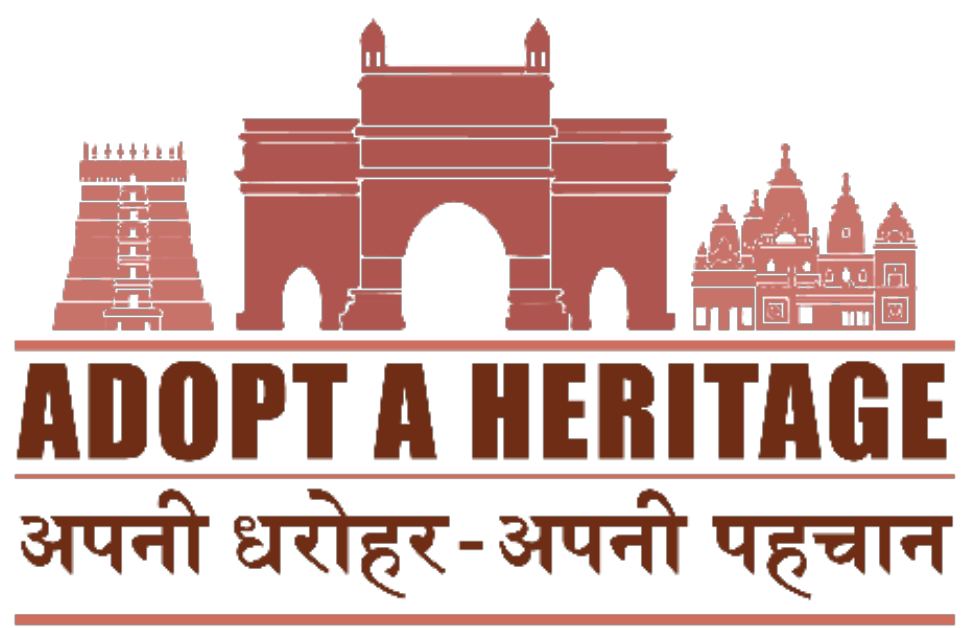

Source: https://www.adoptaheritage.in/

13 Significantly, the three structures selected to symbolize the nation's patrimony are a South Indian Gopuram temple similar to Madurai's Meenakshi temple (left), the colonial Gateway of India in Mumbai (center), and a Sikh gurdwara akin to the Gurdwara Bangla Sahib of Delhi (right). As if to emphasize the message conveyed by the image, the motto placed under the name of the program states: "Your own heritage, your own identity" (aapni dharohar, aapni pahachaan). If one follows the program's catchphrase, the lack of reference to the Islamic component of Indian heritage in the logo directly leads to the idea that national identity is similarly exclusive of that same component. In other words: two years before the Citizenship Amendment Bill, Muslims were thus quite explicitly warned that they had no claim over India's past nor any right to an Indian identity. Interestingly, an altogether different picture emerges from a 
cross-examination of the program's official lists of potential sites for adoption, of sites currently under adoption, and of sites adopted through the signature of MoUs.

Table 2: Typology of the sites selected for the Adopt a Heritage Scheme

\begin{tabular}{|c|c|c|c|}
\hline \multicolumn{2}{|c|}{$\begin{array}{l}141 \text { Heritage Sites up for Adoption (2017) } \\
\text { Compiled from the AAH lists of potential sites } \\
\text { for adoption, of sites under adoption, and of } \\
\text { MoUs signed }\end{array}$} & $\begin{array}{l}\text { Compiled from the AAH lists of } \\
\text { adoption and of MoUs signed }\end{array}$ & under \\
\hline Natural Heritage Site: 9 & $\begin{array}{c}6,5 \\
\%\end{array}$ & Natural Heritage Site: 3 & $5 \%$ \\
\hline Hindu Built Heritage Site: 72 & $51 \%$ & Hindu Built Heritage Site: 30 & $47 \%$ \\
\hline $\begin{array}{c}\text { Non-Hindu Built Heritage Site: } 53 \\
-\quad \text { Islamic: } 35 \\
* \text { Mughal: } 8\end{array}$ & $\begin{array}{c}38 \% \\
25 \% \\
5,5 \\
\%\end{array}$ & $\begin{array}{c}\text { Non-Hindu Built Heritage Site: } 29 \\
\text { - Islamic: } 23 \\
* \text { Mughal: } 8\end{array}$ & $\begin{array}{c}45 \% \\
36 \% \\
12,5 \\
\%\end{array}$ \\
\hline $\begin{array}{l}\text { - Christian: } 11 \\
\text { - Other: } 7\end{array}$ & $\begin{array}{l}8 \% \\
4,5 \\
\%\end{array}$ & $\begin{array}{l}\text { - Christian: } 5 \\
\text { - Other: } 1\end{array}$ & $\begin{array}{c}8 \% \\
1,5 \%\end{array}$ \\
\hline Mixed Built Heritage Site: 7 & $\begin{array}{c}4,5 \\
\%\end{array}$ & Mixed Built Heritage Site: 2 & $3 \%$ \\
\hline
\end{tabular}

Sources: https://www.adoptaheritage.in/pdf/indicative_list.pdf ("list of potential sites for adoption"); https://www.adoptaheritage.in/pdf/list_of_adopted_sites_2017.pdf ("list of sites opted till date"); https://www.adoptaheritage.in/mou.html ("list of MoUs signed under Adopt a Heritage project")

14 According to the above typological chart, not only do Islamic architectural artifacts represent a quarter of the sites put up for adoption, which signals a blatant contradiction between the program's marketing and its concretization. But Islamic heritage sites also appear to be proportionally more coveted than Hindu vestiges in the eyes of the above-mentioned "Monument Mitras": whereas 66\% of the former are being (or have been) brought under the neo-liberal care of private corporations, the rate drops to $40 \%$ in the case of the latter. How is one to interpret these empirical data? Are they the result of a conscious policy on the part of the "seller"-auctioneer, and do they indicate that the Indian state, as governed by the BJP, is more amenable to privatizing Indo-Islamic monuments than Hindu ones? If so, such a policy would be in direct contradiction to the AAH marketing strategy outlined above. Another possibility is that these data rather reflect the inclinations of the "buyers" (the "Monument Mitras") who, for reasons that remain to be explored, seem to proportionately consider the adoption of an Indo-Islamic architectural artifact more desirable or profitable than that of a Hindu one. Whatever may be the case, one important contrast needs to be emphasized at this point of the essay. When the BJP government devises new publicfunded programs of heritage preservation and promotion, not a paisa goes to IndoMuslim historical buildings. ${ }^{12}$ But when it comes to privatizing heritage conservation and management, these same Indo-Muslim artifacts are in the front line even though this is not something the Hindu right seems willing to publicize.

However, as hinted above in the introduction, BJP heritage policies are not geared towards the sole preservation of the material past. Despite the central role Indian history has been playing in Hindutva ideology ever since its inception (see e.g. the article by Audrey Truschke in this volume), it is as if, in a sense, the past-as incarnated by historical buildings-was not enough and therefore had to be supplemented and ruthlessly edited through the creation of new heritage artifacts. ${ }^{13}$ The next section of 
the article examines in this light a series of colossal statues and Disney-like projects that have recently been popping up throughout India.

\section{Enlarge your heritage?}

Starting in the late 1990s when the BJP took control of the central government for the first time with Atal Bihari Vajpayee (d. 2018) as Prime Minister, a mania for ever taller statues celebrating Hindu historical and mythical figures has been fast spreading across India. Among the dozen examples I have been able to identify so $f a r,{ }^{14}$ half call for special attention because the funding for their conception and construction reliespartially or entirely-on public money. These six monumental projects are summarized in the table below for the readers' convenience. ${ }^{15}$

Table 3: Six Hindutva colossi

\begin{tabular}{|c|c|c|c|c|c|c|}
\hline $\begin{array}{l}\text { Dedicate } \\
\text { e }\end{array}$ & Location & $\begin{array}{c}\text { Commissioner(s } \\
\text { ) }\end{array}$ & Cost & Financer(s) & Height & Chronology \\
\hline $\begin{array}{l}\text { Prithviraj } \\
\text { Chauhan }\end{array}$ & $\begin{array}{l}\text { Ajmer, } \\
\text { Rajasthan }\end{array}$ & $\begin{array}{l}\text { Local BJP } \\
\text { government }\end{array}$ & $?$ & $\begin{array}{l}\text { Local BJP } \\
\text { government }\end{array}$ & $\sim 10 \mathrm{ft}$ & $\begin{array}{l}\text { Completed } \\
\text { in } 1996\end{array}$ \\
\hline $\begin{array}{l}\text { Prithviraj } \\
\text { Chauhan }\end{array}$ & Delhi & $\begin{array}{l}\text { Jagmohan, M/o } \\
\text { Urban } \\
\text { Development } \\
\text { and } \\
\text { subsequently } \\
\text { M/o Tourism } \\
\text { and Culture }\end{array}$ & ? & $\begin{array}{l}\text { Central } \\
\text { government } \\
\text { controlled by } \\
\text { the BJP }\end{array}$ & $18 \mathrm{ft}$ & $\begin{array}{l}\text { Conceived } \\
\text { in 1999, } \\
\text { completed } \\
\text { in } 2002\end{array}$ \\
\hline $\begin{array}{l}\text { Sardar } \\
\text { Patel }\end{array}$ & $\begin{array}{l}\text { Kevadiya } \\
\text { colony, } \\
\text { Gujarat }\end{array}$ & $\begin{array}{l}\text { BJP government } \\
\text { of Gujarat }\end{array}$ & $\begin{array}{l}\text { INR Crores 2,900 } \\
\text { (total) }\end{array}$ & $\begin{array}{l}\text { BJP } \\
\text { government of } \\
\text { Gujarat (for } \\
\text { more than } \\
\text { 50\%), federal } \\
\text { government, } \\
\text { public } \\
\text { donations }\end{array}$ & $\begin{array}{l}597 \\
\mathrm{ft} / 182 \mathrm{~m}\end{array}$ & $\begin{array}{l}\text { Conceived } \\
\text { in 2013, } \\
\text { completed } \\
\text { in } 2017\end{array}$ \\
\hline Shivaji & $\begin{array}{l}\text { Mumbai, } \\
\text { Maharashtra }\end{array}$ & $\begin{array}{l}\text { Government of } \\
\text { Maharashtra }\end{array}$ & $\begin{array}{l}\text { INR Crores 2,500 } \\
\text { (estimated) }\end{array}$ & $\begin{array}{l}\text { Government } \\
\text { of } \\
\text { Maharashtra }\end{array}$ & $\begin{array}{l}413 \\
\mathrm{ft} / 126 \mathrm{~m}\end{array}$ & $\begin{array}{l}\text { Conceived } \\
\text { in 2004, } \\
\text { revamped } \\
\text { in 2016, } \\
\text { pending } \\
\text { since } \\
\text { January } \\
2019\end{array}$ \\
\hline Rama & $\begin{array}{l}\text { Ayodhya, } \\
\text { Uttar } \\
\text { Pradesh }\end{array}$ & $\begin{array}{l}\text { BJP government } \\
\text { of Uttar Pradesh }\end{array}$ & $\begin{array}{l}\text { INR Crores 2,500 } \\
\text { (estimated) }\end{array}$ & $\begin{array}{l}\text { BJP } \\
\text { government of } \\
\text { Uttar Pradesh }\end{array}$ & $\begin{array}{l}823 \\
\mathrm{ft} / 251 \mathrm{~m}\end{array}$ & $\begin{array}{l}\text { Conceived } \\
\text { in } 2017 \text {, in } \\
\text { progress }\end{array}$ \\
\hline Hanuman & $\begin{array}{l}\text { Hampi, } \\
\text { Karnataka }\end{array}$ & $\begin{array}{l}\text { Hanumad } \\
\text { Janmabhoomi } \\
\text { Theertha } \\
\text { Kshetra }\end{array}$ & $\begin{array}{l}\text { INR Crores 1,200 } \\
\text { (estimated) }\end{array}$ & $\begin{array}{l}\text { Hanumad } \\
\text { Janmabhoomi } \\
\text { Theertha } \\
\text { Kshetra, BJP } \\
\text { goverment of } \\
\text { Karnataka, } \\
\text { donations of } \\
\text { devotees }\end{array}$ & $215 \mathrm{~m}$ & $\begin{array}{l}\text { Conceived } \\
\text { in } 2020 \text {, in } \\
\text { progress }\end{array}$ \\
\hline & & & $\begin{array}{l}\text { Minimum Total } \\
= \\
\text { INR Crores } \\
9,100 / € 1 \mathrm{~B}\end{array}$ & & & \\
\hline
\end{tabular}

Sources: Talbot (2016:2-3 and 262-266) (Prithviraj Chauhan memorials); https://en.wikipedia.org/ wiki/Statue_of_Unity, BBC News Staff (2018) (Sardar Patel's statue); https://en.wikipedia.org/wiki/ Shiv_Smarak, Jain (2016), Chatterjee (2019) (Shivaji memorial); Arnimesh (2020) (Rama's statue); http://kishkindha.org/statue-of-devotion/, Swamy (2020) (Hanuman's statue) 
Figure 3: Prithviraj Chauhan memorial in Ajmer, @Aagyo ajmer

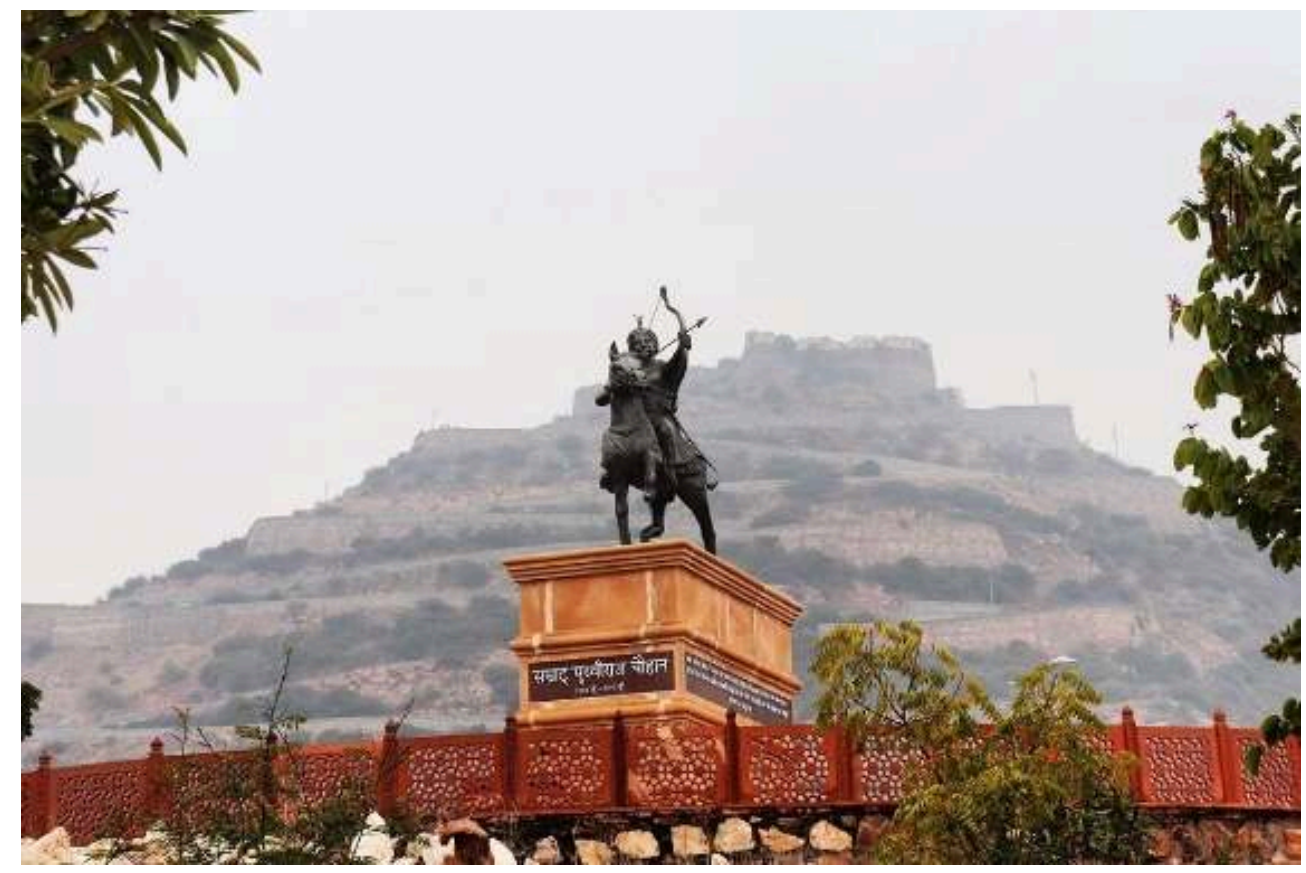

Source: https://upload.wikimedia.org/wikipedia/commons/9/9b/

Aagyo_ajmer_\%28krash_chauhan\%29_of_ajmer_royal_family_of_ajmer_decendant_of_samrath_chauhan.jpg

Figure 4: Prithviraj Chauhan memorial in Delhi, @ आशीष भटनागर

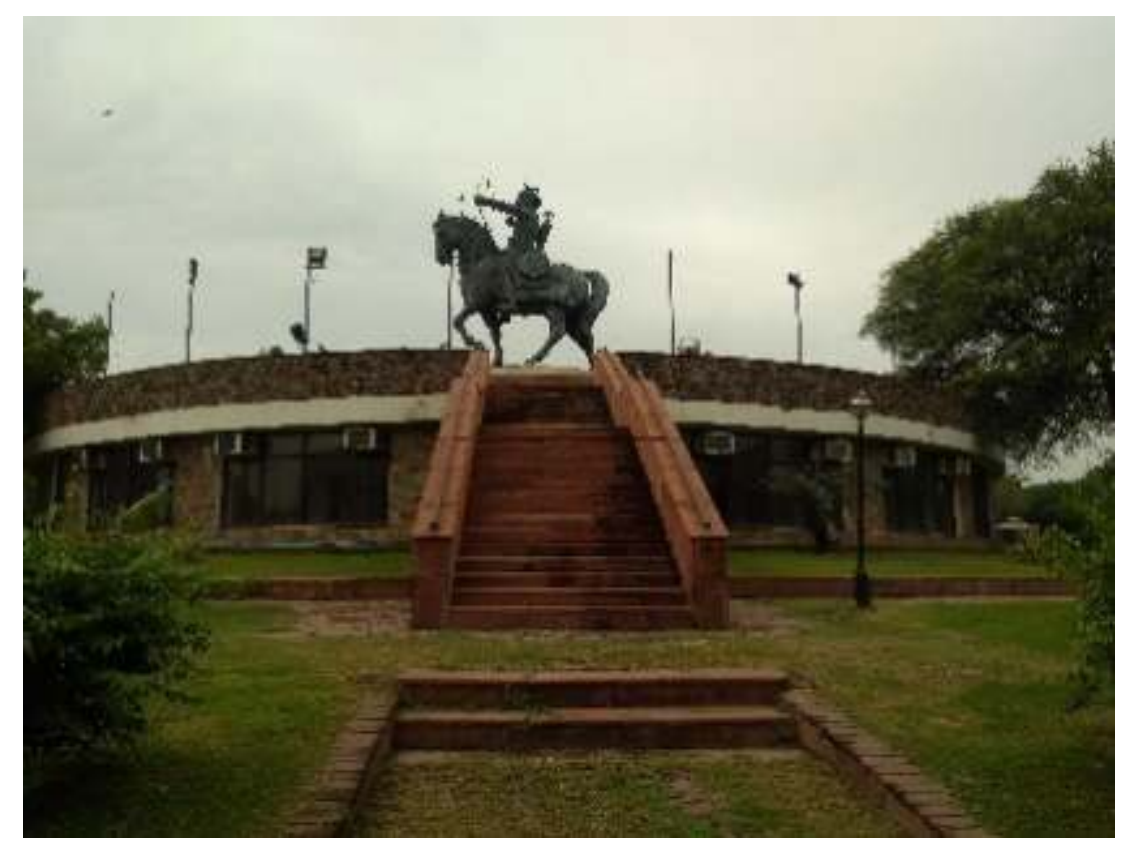

Source: https://commons.wikimedia.org/wiki/

File:Prithviraj_Chauhan_III_statue_at_a_distance_at_Qila_Rai_Pithora,_Delhi.jpg 
Figure 5: Sardar Patel statue in Gujarat, @ Vijay B. Barot

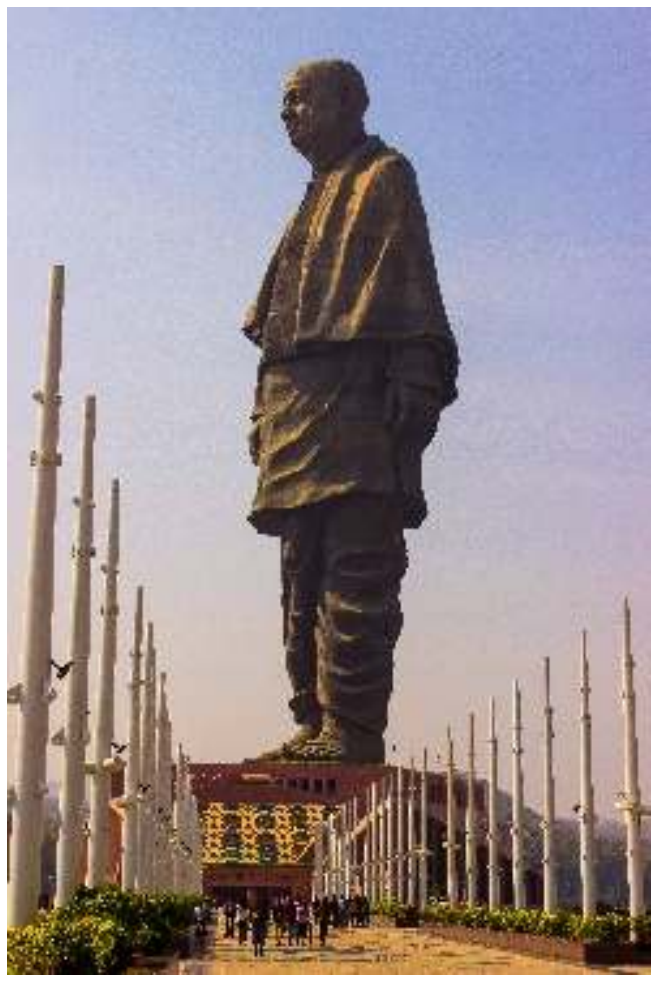

Source: https://en.wikipedia.org/wiki/Statue_of_Unity\#/media/File:Statue_of_Unity.jpg

Figure 6: Model of Shivaji memorial in Mumbai

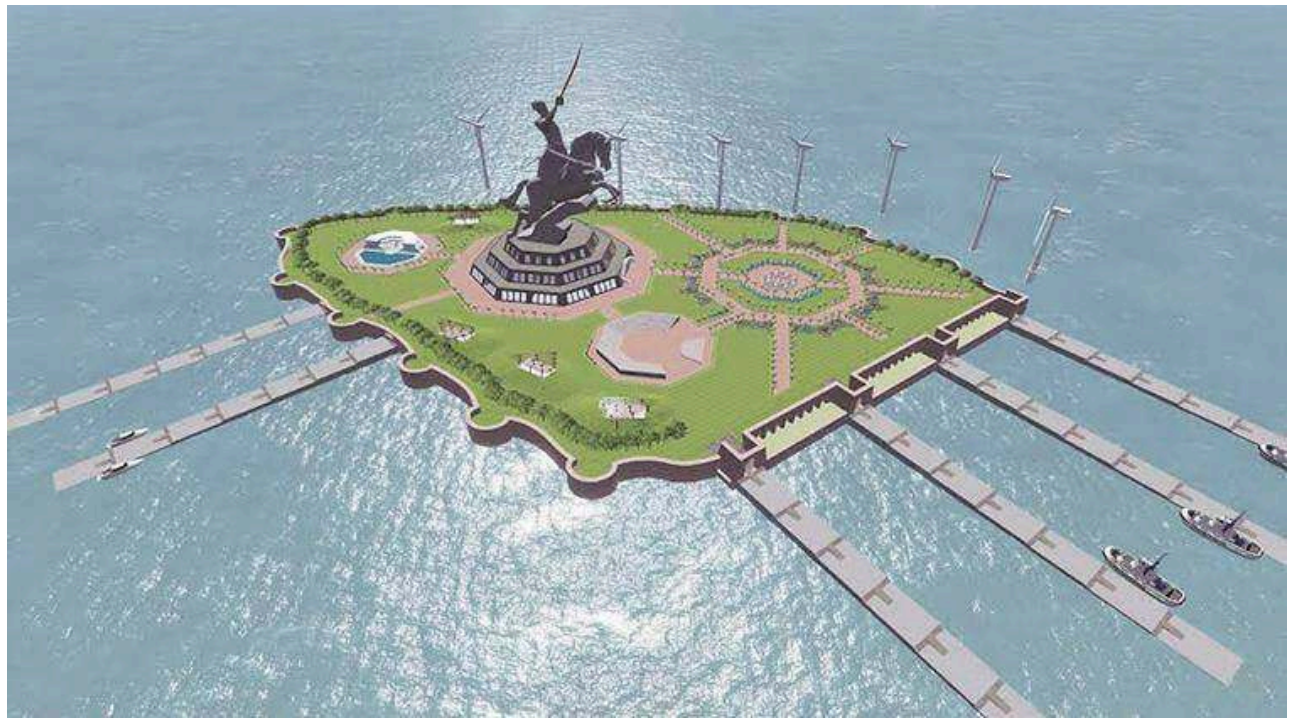

Source: https://indianexpress.com/article/india/for-shivaji-memorial-maharashtra-makes-sculptureshorter-sword-taller-5261027/ 
Figure 7: Model of Ram statue in Ayodhya

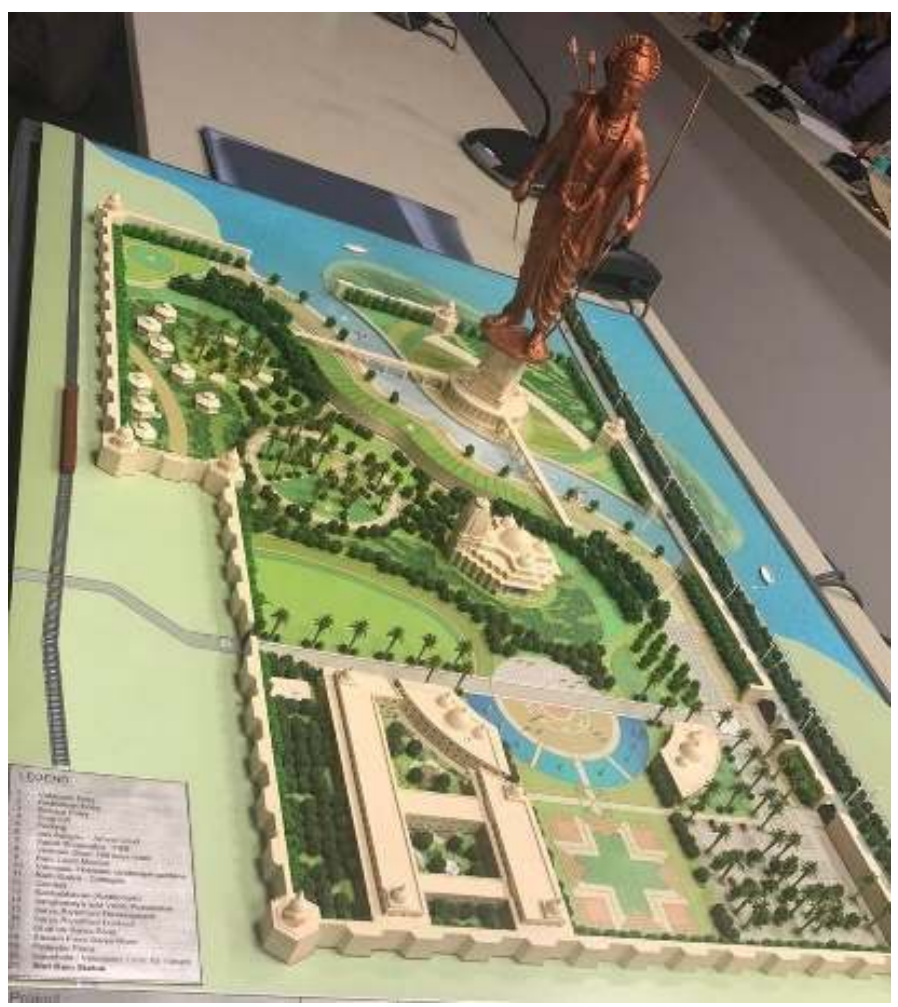

Source: https://indianexpress.com/article/india/yogi-adityanath-ram-statue-ayodhya-dharmasabha-5463026/

Figure 8: Model of Hanuman statue in Hampi, @ Youtube/Hanumad Janmabhoomi Teertha Kshetra Trust

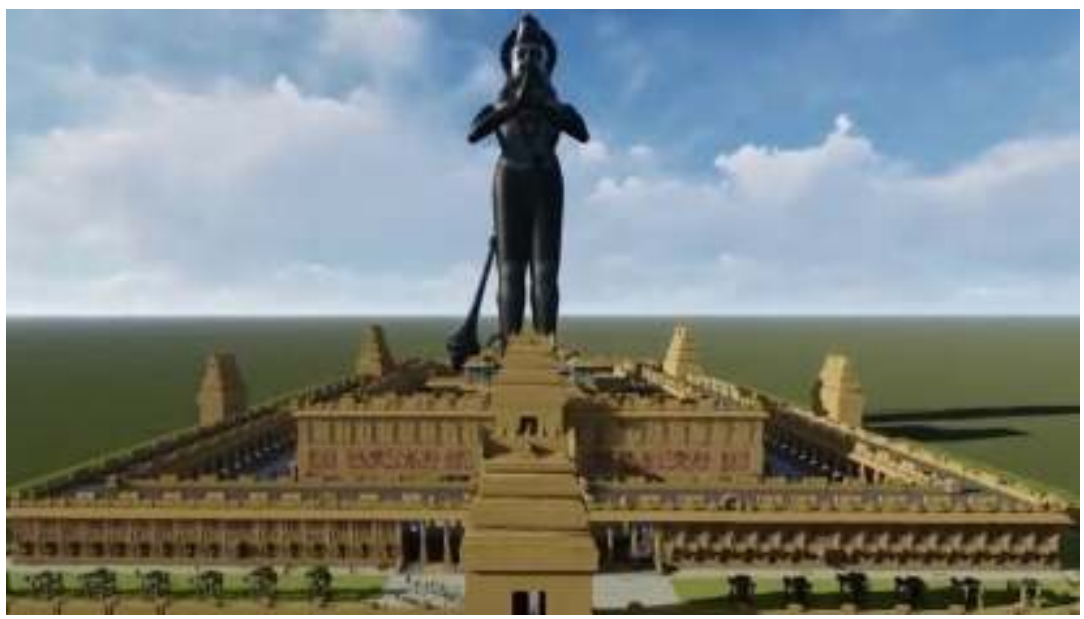

Source: https://theprint.in/india/private-trust-in-karnataka-to-erect-215-m-statue-of-hanuman-inhampi-at-cost-of-rs-1200-cr/476164/

17 In contradistinction to what the AAH privatizing scheme and the structurally understaffed and under-funded ASI might suggest, these six statues first indicate that state finances for heritage are not that scarce. As a matter of fact, the known cumulated funds allocated to the building of these structures $(9,100$ crores) amount to almost twice the sum that has been granted to the SDS since 2015 (5,895 crores) and, more crucially, nine fold the 2020-2021 budget of the Archeological Survey of India (1,246 
crores $\left.^{16}\right)$. If one is to judge by the quantity of public money spent, it would then appear that, in the eyes of the BJP's leaders, heritage is about the creation of Hindutvaglorifying monumental artifacts rather than about the preservation (however biased) of India's archaeological and historical sites.

The Hindutva character of these newly built or in the making structures is evidenced by two elements. One is the identity of their patrons, that is to say those individuals or institutions who initially commissioned the effigies and provided the necessary funding for the concretization of the projects (including the acquisition of the land selected as construction site). With the partial exception of the Mumbai Shiv smarak (Shivaji memorial) whose history is admittedly more sinuous, ${ }^{17}$ every one of the abovementioned monuments has been conceived and financed by figures associated to the Sangh Parivar. Prithviraj's memorial park in Ajmer was created at a time when the government of the Rajasthan state was controlled by the BJP, while the Delhi Qila Rai Pithora Park was built under the aegis of Jagmohan during his mandate as a BJP Member of Parliament for Delhi and his successive tenures as Union Cabinet Minister of Urban Development and for Tourism and Culture in the Vajpayee government (Talbot 2016:2-3 and 262-266). Sardar Patel's Gujarat statue and the planned colossal Rama of Ayodhya are, for their part, well known pet projects of two leading figures of the BJP, India's Prime Minister Narendra Modi and the Chief Minister of UP, Yogi Adityanath, respectively (see e.g. BBC News Staff 2018 and Arnimesh 2020). The case of the latest offspring of the present statuary frenzy is slightly different since its commissioner is a private trust affiliated to the RSS; however, the fact that this organization was able to enlist the BJP government of Karnataka to financially support the project fully legitimates its inclusion here. ${ }^{18}$

The second Hindutva-marker of these statues is the particular subsets of the Indian past and culture they purposely emphasize. Let us first take a look at the three historical figures they showcase. Beyond their Hindu identity, the twelfth-century Rajput petty king Prithviraj Chauhan (d.1192), the seventeenth-century Maratha warlord Shivaji (d.1680) and the twentieth-century Congress leader and freedom fighter Sardar Patel are deemed worthy of monumentalization because they represent, in the eyes of Hindu rightists, successive and dramatic moments of Hindus' supposed multi-secular fight against foreign invaders. Whereas Prithviraj's and Shivaji's recasting as Hindu heroes fighting the Muslim barbarians and oppressors (Ghurid and Mughal rulers) can be traced back to nineteenth-century nationalist historiography (Talbot 2016 and Laine 2003), Patel's appropriation by the Hindu right is a much more recent and paradoxical phenomenon. Unlike Prithviraj and Shivaji who died centuries before the appearance of Hindutva in India's political landscape, Patel was witness to the emergence of the movement and staunchly opposed it (Sircar 2019). In this sense, his attempted cooptation by N. Modi-which may be explained by a mixture of regional electioneering reasons and the will to make up for the absence of Hindutva leaders within the nationalist pantheon-is no less a bewildering tour de force than the fashioning of his colossal effigy out of-rather than in-India. ${ }^{19}$ The other figures selected for monumentalization are two star deities of the Ramayana, the celebrated Sanskrit epic. As is well known, Rama and, to a lesser extent, his companion Hanuman have long been given pride of place within Hindutva Hinduism. ${ }^{20}$ Among the many transformations entailed by such a "spiritual" takeover, the efforts made by the Sangh Parivar to historicize these mythical figures are of paramount importance to 
understand what is at stake behind the planned building of their mammoth statues. Echoing the edification-past and present-of "janmabhumi mandirs" or "birthplace temples," each effigy is to be located at the site where gods Rama and Hanuman were supposedly born, in Ayodhya and Hampi respectively. In other words, what is happening with these two gigantic idols goes far beyond the above-mentioned Hindutva hijacking of historical figures: much more disturbingly, the story they tell is about the promotion of the sacred topography of Hinduism as India's new historical geography.

The present Indian frenzy of giant statue building inevitably brings to mind the architecture of former fascist regimes and their sculptural self-fashioning as heirs of lost empires and golden ages, first among which Mussolini's Italy and its nostalgia for long bygone Roman glories. Just like the majoritarian Hindu state heralded and incarnated by the BJP is working to establish a segregated nation-state where nonHindus are reduced to second-class citizens with shrinking rights, the architectural heritage through which it strives to achieve posterity is meant to crush-by the sheer gigantism of its artifacts-the non-Hindu elements of India's built landscape. In a more vulgar way, this competition to build ever bigger also evokes a kind of phallic cockfight between the male leaders of the Hindu right: N. Modi as Gujarat Chief Minister and then as India's Prime Minister, Uddhav Thackeray as Maharashtra Chief Minister, Yogi Adityanath as Uttar Pradesh Chief Minister, and B. S. Yediyurappa as Karnataka Chief Minister. And since eighteen of the thirty-one Indian states are presently ruled by the BJP (alone or through a coalition), the ongoing race to "build taller, feel greater" is probably not going to stop any time soon.

21 If the aggressive monumentality of this series of colossal statues in the making brings to mind fascist Italy, the kind of amenities they include or will eventually include (artificial lakes, gardens, exhibition halls with life-sized representations, reconstructed sites, digital dioramas, food courts, etc.) rather conjures up Disneyland and the theme park model that has become a global phenomenon since the 1990s. In this sense, they partake in what Alan Bryman (2004) has called the "Disneyization of society," a process that, among others things, "deals in cultivated nostalgia and in playfulness about reality" (Lyon 2000:6).

Like the fever for giant statues celebrating Hinduness, theme parks aiming at disseminating Hindu nationalist fervor date back to the late 1990s-the Delhi Akshardham Cultural Complex (2005) being among the best known examples ${ }^{21}$-and they are fast becoming a privileged propaganda tool in the hands of BJP leaders. In this regard, Yogi Adityanath's plans to expand religious tourism in Uttar Pradesh are a case in point (on this figure, see the contribution by V. Bouillier in this volume). In July 2017, a couple of months after his election as Chief Minister and a few weeks before the Taj Mahal was excluded from the state government's list of major attractions (Pandey 2017), the Gorakhpur-monk-turned-politician announced his intention to have an amusement park dedicated to Krishna built in Mathura, the presumed birthplace of the god (Darade 2017). Since then, a "Krishna Fun Land" developed by the real estate Braj Bhoomi Group has indeed opened in Mathura, but it does not seem to include the grand reconstruction of Krishna's life that was initially planned. ${ }^{22}$ For Adityanath's attention is currently entirely directed to another project, which was likewise first advertised in 2017: the above-mentioned Rama statue, destined to be one of the highlights of the larger "Navya (New) Ayodhya" scheme. Aiming at developing Ayodhya 
as a global touristic hub, the project has naturally been boosted by the Supreme Court's verdict in November 2019 and the ensuing first steps taken towards the construction of a new Rama temple on the site of the Babri Masjid for which N. Modi laid the foundation stone on August 5, 2020 (BBC News Staff 2020). In order to offer the visitor a "holistic Indic experience," Navya Ayodhya should house the largest theme park ever built in India. Spreading over 100 acres on the banks of the Saryu river along the Lucknow-Gorakhpur national highway, this "Eye Theme Park" will not only include the 823 feet-statue of Rama but also lively reconstructions of the major sites of the Ramayan ${ }^{23}$ and an International Ram Katha museum ${ }^{24}$ offering depictions from Rama's "life" in addition to the digital museum and interpretation center situated underneath the giant idol (Sharma 2019). Today however, despite repeated official announcements and the wide media coverage it has been receiving since 2017, the New Ayodhya's "Eye Theme Park," which its advocates and promoters see as heralding the advent of the long awaited "Ram Rajiya" or "Rama's Realm," still boils down to a cascade of water slides. For, just like the earlier Patel and Shivaji statue projects, it keeps running against human and natural obstacles. ${ }^{25} \mathrm{After}$ a failed attempt in Meerpur Duaba, the UP administration decided in 2019 to relocate the construction site in the neighboring district of Manja Barhata but it is meeting with little success there too: while local villagers and farmers are opposing land acquisition by the state, the district magistrate Anuj Kumar Jha has recently (January 2020) banned the construction process due to environmental non-conformity. ${ }^{26}$

Despite the grotesque character of the recent Hindutva heritage creative outburst and the irresistible irony underpinning its above presentation, one should certainly not underestimate the potential impact of these artifacts on their targeted audience, i.e. Hindu tourists and pilgrims from India or the diaspora. Once lured into such postsecular circuses and exposed to Hindutva soft power, there is a good chance that the still hesitant among the visitors will eventually embrace the Hindu Rashtra project, whether consciously or not. In this respect, the BJP's Disney-like heritage architecture appears no less dangerous than the darkest side of the Hindu right's heritage policy aiming at the obliteration of India's non-Hindu heritage: at the very least, it contributes to the acceptation and acceptability of the growing violence perpetrated against Islamic monuments and Indian Muslims; at worst, it may trigger participation in such acts.

\section{Memoricide ${ }^{27}$ under way: Indo-Muslim built landscape in Hindu Rashtra}

Ever since its inception in the 1920s, the Hindu nationalist movement has placed South Asian Muslims and the Indo-Muslim past at the top of its hate list. To a far greater degree than Christians and the British Raj, they have come to embody the ultimate Other and been made responsible for the centuries-long eclipse of the once glorious civilization of ancient India. Although the Sangh Parivar's anti-Muslim stance and the violence committed against Indo-Muslim individuals and monumental artifacts is probably the one aspect of the ethno-religious populist movement that has received the widest media coverage and the greatest scholarly attention, these recurrent assaults bear repetition here, as do the most salient features of the process of obliteration 
underpinning them. For the sake of concision, these attacks may be summarized as taking part in a two-pronged strategy-turned-policy.

The first (and harder) prong is about mythicizing, to mystify in order to lay claim over and eventually (in a growing number of cases) destroy Indo-Muslim built architecture. The Babri Masjid-Ram Janmabhumi dispute is the best known example of such tactics and of their successful outcome. Although no archeological or historical evidence documents the role of present-day Ayodhya (Uttar Pradesh) as a Hindu center of pilgrimage before the early modern period (Bakker 1982), Hindutva ideologues and aficionados have long held that god Rama was a native of the city and that a temple had stood at the exact location of his birth until it was destroyed in the sixteenth century by the accursed Mughals who built in its stead a mosque erroneously known as the Babri Masjid. ${ }^{28}$ In the 1980s, the Vishwa Hindu Parishad (VHP, or World Hindu Council) and other Hindu nationalist groups and political parties (including the BJP) launched a massive campaign to avenge this invented act of iconoclasm and to erect a temple dedicated to Rama on the contended site. The movement first climaxed in early December 1992 when a huge mob of kar sevaks ("temple volunteers") razed the mosque to the ground which, in turn, triggered a wave of communal riots across India and resulted in the death of over 2,000 people, mainly Muslims. A second acme was reached on November 9, 2019 when the Indian Supreme Court returned its long-awaited verdict on the dispute: although it admitted that there was no hard evidence of a preexistent temple and that the destruction of the Babri Masjid had been an illegal coup de force, it still awarded the site to a government-appointed trust (the Shri Ram Janmabhoomi Teerth Kshetra, founded in February 2020) under whose authority a "new" Ram Mandir is currently being built. Not only did the judgment amount to a symbolic reenactment of the 1992 demolition; it also set a lethal precedent legitimating the use of "extrajudicial violence as an acceptable means of changing the built landscape of India" (Truschke 2020). In other words, ethno-religious terrorism is fast becoming an official tool for the management of dissonant heritage under the rule of the BJP.

As a matter of fact, a number of Hindu nationalist groups are already on the move to capitalize on the breach caused by the verdict, especially with regard to the 1991 Places of Worship Act. ${ }^{29}$ Unsurprisingly, the BJP is leading the way. In the week following the judgment, C. T. Ravi, the then Karnataka minister of tourism, declared that the BJP government of the state was gearing up to find an out-of-court solution to the Baba Budangiri dargah-Dattatreya peetha dispute (Yogesh 2019). In March 2020, while the COVID-19 pandemic was descending upon India, the Akhil Bharatiya Sant Samiti, an umbrella body of Hindu seers, announced its determination to free "the Kashi Viswanath temple from the stranglehold of the Gyanvapi mosque" in Banaras (Tripathi 2020). A few months later, in June, the Vishwa Bhadra Pujari Purohit Mahasangh, a Lucknow-based association of Hindu priests, openly challenged the 1991 Places of Worship Act in order to liberate the Shahi Idgah mosque of Mathura (as well as the Gyanvapi Masjid) on the lines of the Ram Janmabhumi movement (Nair 2020). ${ }^{30}$ Following on the heels of these recently created or relatively minor organizations, the much more prominent Hindu Mahasabha heartily embraced their claims and called out Indian Muslims to hand over the Banaras and Mathura mosques as "a message of peace to the world" (Awashthi 2020). Neither the fact that the influential VHP and RSS have so far refrained from officially supporting such demands nor the recent rejection by the Mathura court of yet another petition seeking the eradication of the Shahi Idgah 
mosque offer any reassurance as regards the prospect of these minor early modern Islamic shrines (Chatuverdi 2020).

To a limited extent, this plight may be contrasted with the situation of the masterpieces of Indo-Muslim architecture, best known among them those that were built during the Mughal period. If none is in imminent danger of annihilation yet, a number of them are nonetheless the object of a relentless process of mythicization or de-historicization. In this regard, the fortune of a series of writings penned by members of the Institute for Rewriting Indian History is a case in point. Starting in the mid-1960s, Purushottam Nagesh Oak and Hansraj Bhatia published various essays claiming that a whole array of Mughal monuments (from the Taj Mahal to Fatehpur Sikri, including the palace-fortresses of Agra and Delhi) were actually the product of earlier Hindu patronage and had formerly been the sites of temples or Rajput palaces (Oak 1965 and 1976; Bhatia 1969 and 1971). Despite the fact that neither Oak nor Bhatia provided the slightest shred of hard evidence to support such allegations and that their books were published at the author's expense or by minor presses half a century ago, the myths they forged have since then enjoyed a far wider circulation than any academic monograph on Mughal architecture thanks to "a massive network of electronic and paper publications" orchestrated by the Sangh Parivar (Asher 2009:21).

With the BJP's 2014 victory at the general elections and its taking control of an increasing number of states, this process of de-historicization coupled with vilification is logically gaining momentum. Not only are these fanciful tales on the verge of becoming a new received wisdom thanks to the official support they regularly receive from BJP Members of Parliament such as Laxmikant Bajpai and Vinay Katiyar; they also have started to fuel concrete political actions such as the above-mentioned exclusion of the Taj Mahal from the UP's official touristic brochure in 2017 (Beaty 2018). Even though the latter act may seem trifling compared to the sacking of the Mughal mausoleum by a VHP mob in 2018 (not to mention its complete annihilation as presaged by Prayaag Akbar's novel Leila and its adaptation by Deepa Mehta as a Netflix series), it is worth pondering on this episode and its significance for at least two reasons. 
Figure 9: The annihilation of the Taj Mahal as anticipated by Leila, S01E02

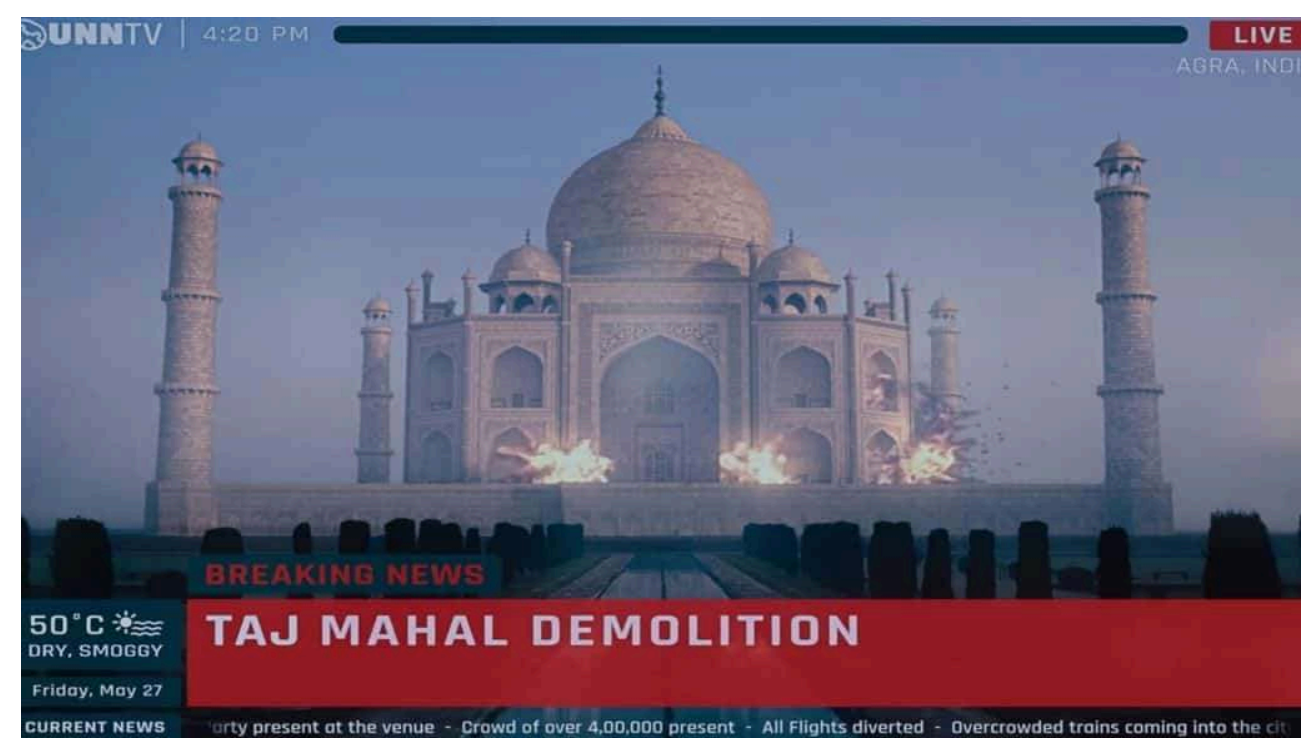

Source: https://moviemahal.net/2020/07/30/leila-dir-deepa-mehta-2019-india/ building statues and theme parks celebrating the eternal glory of Hinduness: the peppering of Indian public (especially urban) space with such artifacts inevitably results in the physical marginalization of the Indo-Muslim component of the national built landscape. It is also a much safer path to follow where (international) public opinion is concerned for, however fiercely it may be criticized, it generally eludes the opprobrium cast on iconoclastic violence, especially when the latter threatens UNESCO World Heritage Sites.

31 Another potent spatial manifestation of the re-Hinduization orchestrated by the promoters of Hindu Rasthra has to do with names, particularly with toponyms. ${ }^{31}$ As is well known, (re)naming a place is at once a cosmological act for the one who performs it and an identity marker for those who afterwards live in or research that same place. Like most imperial regimes in the past (including the Mughals), it is therefore hardly surprising that the representatives of the political branch of the Sangh Parivar have set about refashioning India's toponymy. Echoing the ongoing efforts at remodeling the nation's built landscape, they are working hard to remove the innumerable lexical and semantic traces that the centuries-old presence of Muslims has left throughout the country. Among the early experiments carried out in this domain, the reconstruction of several villages in the wake of the severe earthquake that hit the district of Kachchh (Gujarat) in January 2001 is particularly instructive. Under the supervision of N. Modi, the then chief minister of the state of Gujarat, part of the rehabilitation was entrusted 
to the VHP, as a result of which two localities previously known as Lodai and Dudai were renamed Keshav Nagar (Krishna's city) and Indraprastha (Indra's city) respectively and rebuilt so as to strictly segregate the local Hindu and Muslim populations (Simpson and Corbridge 2006). However, it is only in the wake of the BJP's takeover of the central government in 2014 that this process of renaming has started growing apace. In August 2015, the renaming of Aurangzeb Road in Delhi after A. P. J. Abdul Kalam (d.2015) (figure 10), whose election as the eleventh president of India (2002-2007) had been supported by the BJP, marked a momentous first step in what has since then become a nation-wide movement for replacing Indo-Muslim (especially Mughal) toponyms by place-names either celebrating carefully chosen Muslim figures (such as was the case with A. P. J. Abdul Kalam) or, to a far greater extent, restoring/ evoking the earlier Hindu designations of towns, districts and even railway stations.

Figure 10: Renaming Aurangzeb Road, Delhi, 2015

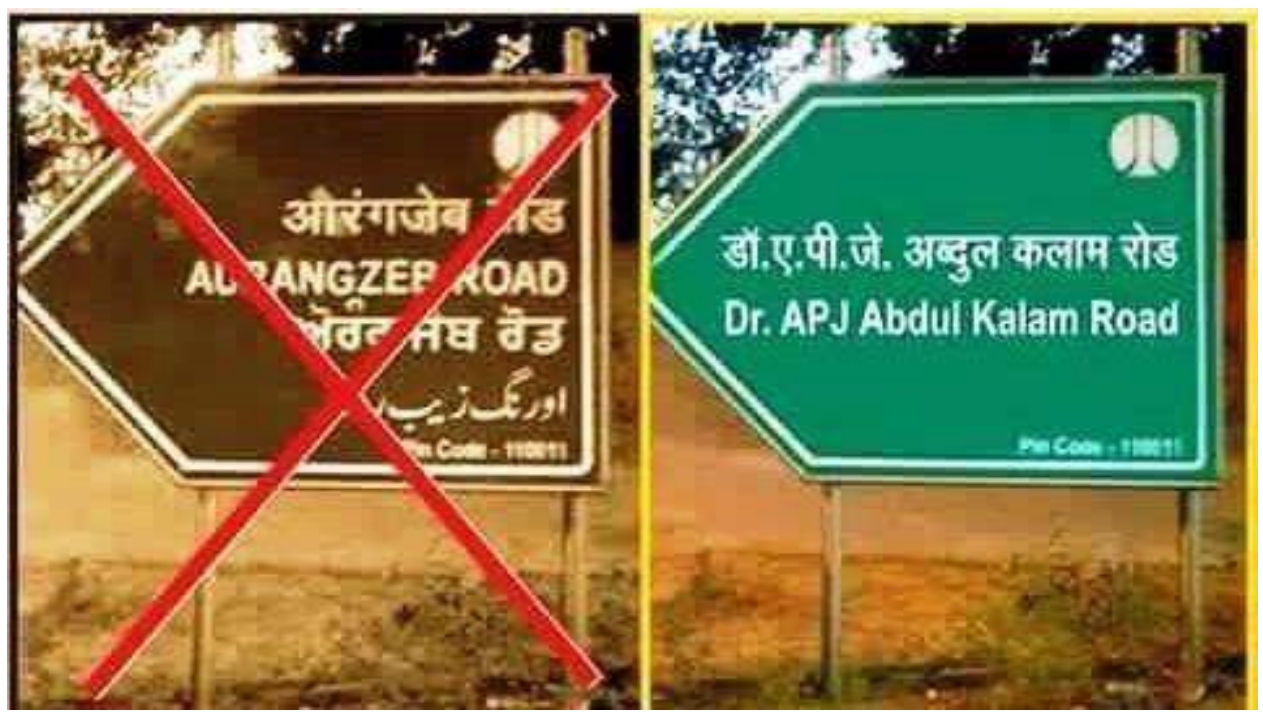

Source: https://www.thenewsminute.com/article/delhi-hc-questions-civic-body-over-renamingaurangzeb-road-33992

Among the many examples subsequent to the renaming of Aurangzeb Road (see e.g. Daniyal 2018 and Truschke 2020 for a provisional list and critical appraisal thereof), the latest targets an under-construction museum in Agra devoted to Mughal history and heritage. Apparently unable to stop the project that had been approved in 2015, Yogi Adityanath retaliated in September 2020 by naming it after the Maratha leader Shivaji (Shaikh 2020). In so doing, the chief minister of UP not only added to the ongoing Hinduization of the city that was once a nerve center of Mughal political domination and culture. ${ }^{32}$ The statements that accompanied his decision-"How can our heroes be Mughals?"-are yet another threat to anyone bold enough to remind the people of Hindu Rashtra that Indo-Muslim history and culture is part and parcel of today's India, whether they like it or not. Such rhetoric of intimidation is proving very effective, as may be seen for instance in a recent declaration by Athar Hussain, the secretary of the Indo-Islamic Cultural Foundation Trust constituted for the construction of Ayodhya's new mosque: while publicly inviting Yogi Adityanath to the inauguration ceremony of the public facilities adjoining the shrine, he made clear that the new Babri Masjid would not be named after Babur or any other Mughal figure (Khan 2020). In view of the new heights that state violence against Muslims has reached since the BJP central 
government revoked Kashmir's special status in August 2019, self-censorship seems to have become the only technique of self-defense available to Indian Muslims and it will most likely spread among non-Hindus in proportion to the memoricide under way. May the latter not swell into genocide. For, if it is the special duty of historians to keep alive the memory of the past, to record and rectify its multiple distortions, resurrecting the dead is definitely out of their reach.

\section{BIBLIOGRAPHY}

Arnimesh, Shanker. 2020. “3 Years On, Yogi Govt yet to Acquire Land in Ayodhya for 'World's Tallest' Ram Statue.” The Print, July 30. Retrieved on November 9, 2020 (https://theprint.in/ india/3-years-on-yogi-govt-yet-to-acquire-land-in-ayodhya-for-worlds-tallest-ram-statue/ 470643/).

Asher, Catherine B. 2009. "Belief and Contestation in India: The Case of the Taj Mahal." Keynote address to the ASIANetwork Conference in Lisle, Illinois, March. Retrieved on November 9, 2020 (https://asianetworkexchange.org/articles/10.16995/ane.212/galley/293/download).

Ashworth, Gregory J. and J. E. Tunbridge. 1996. Dissonant Heritage. The Management of the Past as a Resource in Conflict. Chichester: Wiley.

Awashthi, Puja. 2020. "Hindu Mahasabha wants Kashi, Mathura to be Handed Over in the Name of 'Peace'.” The Week, June 17. Retrieved November 9, 2020 (https://www.theweek.in/news/india/ 2020/06/17/hindu-mahasabha-wants-kashi-mathura-to-be-handed-over-in-name-ofpeace.html).

Bakker, Hans. 1982. “The Rise of Ayodhyā as a Place of Pilgrimage.” Indo-Iranian Journal 24(2):10326.

BBC News Staff. 2020. "India PM Modi Lays Foundation for Ayodhya Ram Temple amid Covid Surge.” BBC News, August 5. Retrieved November 9, 2020 (https://www.bbc.com/news/worldasia-india-53577942).

BBC News Staff. 2018. "India Unveils the World's Tallest Statue." BBC News, October 31. Retrieved November 9, 2020 (https://www.bbc.com/news/world-asiaindia-46028342\#: :text=Image\%20 copyright\%20Getty\%20Images\%20The,\%3B\%20\%24430m) \%20to\%20build).

Beaty, Katelyn. 2018. “Taj Mahal Vandalized as Hindu Nationalists Dispute Site's Muslim Origins.” Religion News Service, June 19. Retrieved November 9, 2020 (https://religionnews.com/ 2018/06/19/taj-mahal-vandalized-as-hindu-nationalists-dispute-sites-muslim-origins/).

Bhatia, Hansraj. 1971. Agra Red Fort is a Hindu Building. Delhi: Surya Prakashan.

Bhatia, Hansraj. 1969. Fatehpur Sikri is a Hindu City. Delhi: Surya Prakashan.

Bhatt, Jagdish. 2010. "World's Tallest Hanuman Statue at Shimla." The Times of India, November 4. Retrieved November 9, 2020 (https://timesofindia.indiatimes.com/india/Worlds-tallestHanuman-statue-at-Shimla/articleshow/6871465.cms). 
Brosius, Christiane. 2010. India's Middle Class: New Forms of Urban Leisure, Consumption and Prosperity. Delhi: Routledge.

Bryman, Alan. 2004. The Disneyization of Society. London: Sage Publications.

Chatterjee, Badri. 2019. "Maharashtra Government Stops Shivaji Memorial Construction." Hindustan Times, January 16. Retrieved November 9, 2020 (https://www.hindustantimes.com/ mumbai-news/maharashtra-government-stops-shivaji-memorial-construction/storynRZXjj9HRGc6bIBihog6rJ.html).

Chatuverdi, Hemenchandra. 2020. "Mathura Court Dismisses Plea for Mosque Removal, Petitioners to Move Higher Court." Hindustan Times, October 1. Retrieved November 9, 2020 (https://www.hindustantimes.com/lucknow/mathura-court-dismisses-plea-for-mosqueremoval-petitioners-to-move-higher-court/story-h74NhtF5RK2KzFOkLKK8eP.html).

Copeman, Jacob and Veena Das (ed.). 2015. On Names in South Asia: Iteration, (Im)propriety and Dissimulation. South Asia Multidisciplinary Academic Journal 12. Retrieved on November 9, 2020 (https://journals.openedition.org/samaj/3985).

Daniyal, Shoaib. 2018. “No Hindi, Hindu, Hindustan? Implemented fully, BJP's Hindutva Renaming will Wipe Out a lot of India." Scroll.in, November 20. Retrieved on November 9, 2020 (https://scroll.in/article/902177/no-hindi-hindu-hindustan-implemented-fully-bjps-hindutvarenaming-will-wipe-out-a-lot-of-india).

Darade, Pooja. 2017. "Uttar Pradesh: Yogi Adityanath Government Plans to Build Disneyland like Krishna Land in Mathura.” India.com, July 16. Retrieved on November 9, 2020 (https:// www.india.com/news/india/uttar-pradesh-yogi-adityanath-government-plans-to-builddisneyland-like-krishna-land-in-mathura-2324255/).

Dave, Hiral. 2018. "Behind the Making of Statue of Unity." Hindustan Times, October 14. Retrieved on November 9, 2020 (https://www.hindustantimes.com/india-news/behind-the-making-ofstatue-of-unity/story-k67YKhhZaXb68ph5Zos54M.html).

Eaton, Richard M. 2000. “Temple Desecration and Indo-Muslim States.” Pp. 246-81 in Beyond Turk and Hindu. Rethinking Religious Identities in Islamicate South Asia, edited by D. Gilmartin and B. B. Lawrence. Gainesville: University Press of Florida.

Frykenberg, Robert E. 2008. "Hindutva as a Political Religion: An Historical Perspective." Pp. 178220 in The Sacred in Twentieth-Century Politics, edited by R. Griffin, R. Mallett and J. Tortorice. New York: Palgrave Macmillan.

Gandhi, Supriya. 2020. "When Toppling Monuments Serves Authoritarian Ends." Foreign Affairs, July 13. Retrieved on November 9, 2020 (https://www.foreignaffairs.com/articles/india/ 2020-07-13/when-toppling-monuments-serves-authoritarian-ends).

Jain, Bhavika. 2016. "Shivaji Memorial Money could have Helped Maharashtra Complete Key Projects.” The Times of India, December 23. Retrieved on November 9, 2020 (https:// timesofindia.indiatimes.com/city/mumbai/shivaji-memorial-money-could-have-helpedmaharashtra-complete-key-projects/articleshow/56130754.cms).

Jain, Kajri. 2018. “Reconfiguring India's Nationalism, One Grand Statue at a Time.” The Wire, October 31. Retrieved on November 9, 2020 (https://thewire.in/politics/narendra-modi-statueof-unity-sardar-patel).

Kanga, Surabhi. 2017. “'Archeology Should Be Taken Out of the Corridors of the Government': Historian Nayanjot Lahiri on the ASI and Preserving Indian Heritage." The Caravan, August 14. 
Retrieved on November 9, 2020 (https://caravanmagazine.in/vantage/historian-nayanjot-lahiriasi-preserving-indian-heritage).

Khan, Arshad Afzaal. 2020. "UP: Mosque Trust to Invite CM Yogi Adityanath for Hospital, School Foundation.” The Times of India, August 9. Retrieved on November 9, 2020 (https:// timesofindia.indiatimes.com/city/lucknow/mosque-trust-to-invite-yogi-for-hosp-schoolfoundation/articleshow/77439064.cms).

Khanna, Rajeev. 2018. “Why the Statue of Unity Hasn't Quite Generated the Euphoria BJP Craved." The Wire, October 31. Retrieved on November 9, 2020 (https://thewire.in/politics/bjpsardar-patel-statue-of-unity-protests).

Kumar, Sushil. 2019. "How Modi's Vishwanath Corridor is Laying the Ground for Another Babri Incident.” The Caravan, April 27. Retrieved on November 9, 2020 (https://caravanmagazine.in/ religion/how-modi-kashi-vishwanath-corridor-is-laying-the-ground-for-another-babri-incident).

Laine, James W. 2003. Shivaji. Hindu King in Islamic India. New York: Oxford University Press. Lutgendorf, Philip. 2007. Hanuman's Tale: The Messages of a Divine Monkey. New York: Oxford University Press.

Lyon, David. 2000. Jesus in Disneyland: Religion in Postmodern Times. Cambridge: Polity.

Meskell, Lynn. 2020. “Toilets First, Temples Second: Adopting Heritage in Neoliberal India." International Journal of Heritage Studies. Retrieved August 20, 2020 (https://www.tandfonline.com/ doi/full/10.1080/13527258.2020.1780464).

Nair, Preetha. 2020. "Kashi, Mathura Next? A Petition in SC Against Place of Worship Act 1991 Sparks Fears of Ayodhya Replay.” Outlook, August 17. Retrieved on November 9, 2020 (https:// magazine.outlookindia.com/story/india-news-kashi-mathura-next-target-a-petition-in-scagainst-place-of-worship-act-1991-sparks-fears-of-replay-of-ayodhya/303526).

Oak, Purushottam Nagesh. 1976. Delhi's Fort is Hindu Lalkot. Bombay: Jaico Publishing House.

Oak, Purushottam Nagesh. 1965. Taj Mahal was a Rajput Palace. New Delhi: The Author.

Pandey, Alok. 2017. "New Slight for Taj Mahal from Yogi Adityanath's Administration." NDTV, October 2. Retrieved on November 9, 2020 (https://www.ndtv.com/india-news/taj-mahalblacked-out-of-up-governments-list-of-major-attractions-1757652).

Pati, Sushmita. 2019. "Building 'Monuments' in a World Class City: Aesthetics and Politics in Contemporary Delhi." Pp. 329-51 in India and its Visual Cultures: Community, Class and Gender in a Symbolic Landscape, edited by U. Skoda and B. Lettmann. Delhi: Sage Publications.

Pati, Sushmita. 2014. “Jagmohan: The Master Planner and the 'Rebuilding' of Delhi." Economic and Political Weekly 49(36):48-54.

Rajagopalan, Mrinalini. 2011. "Postsecular Urbanisms: Situating Delhi within the Rhetorical Landscape of Hindutva." Pp. 257-82 in The Fundamentalist City? Religiosity and the Remaking of Urban Space, edited by N. AlSayyad and M. Massoumi. Abingdon: Routledge.

Roy, Namita and Ulrike Gretzel. 2020. “Themed Route Marketing in India.” Anatolia: An International Journal of Tourism and Hospitality Research 31(2). Retrieved September 7, 2020 (https:// www.tandfonline.com/doi/abs/10.1080/13032917.2020.1747222).

S., Yogesh. 2019. "Baba Budangiri: BJP to Attempt Out-of-Court Settlement?" Newsclick, November 13. Retrieved November 9, 2020 (https://www.newsclick.in/Baba-Budangiri-BJP-Attempt-Out-ofCourt-Settlement). 
Sankaran, P. N. 2019. “CSR Interventions in India under State Invitation: An Artisans' Perspective on 'Adopt a Heritage' Programme.” Pp. 29-51 in The Components of Sustainable Development: Engagement and Partnership, edited by D. Crowther and S. Seifi. Singapore: Springer.

Savarkar, Vinayak Damodar. 1969 [1923]. Hindutva. Who is a Hindu? Bombay: Veer Savarkar Prakashan.

Sayeed, Vikhar Ahmed. 2018. "Bababudangiri. A Battlefront in the South." Frontline, March 2. Retrieved November 9, 2020 (https://frontline.thehindu.com/the-nation/a-battlefront-in-thesouth/article10074157.ece).

Scroll.in Staff. 2017. "Watch: Narendra Modi Unveils Controversial 112-foot Shiva Statue at Isha Foundation.” February, 24. Retrieved November 9, 2020 (https://scroll.in/latest/830219/ protestors-urge-narendra-modi-not-to-unveil-controversial-112-foot-shiva-statue-at-ishafoundation).

Shaikh, Zeeshan. 2020. "Explained: 700-plus Places in India that Bear the Names of Mughals Today." The Indian Express, September 17. Retrieved November 9, 2020 (https:// indianexpress.com/article/explained/mughal-museum-agra-uttar-pradesh-yogi-adityanathchhatrapati-shivaji-maharaj-6596770/).

Sharma, Aman. 2019 “Yogi's Ayodhya's Plans: A Shabri Garden, Ashok Vatika, Ram Setu and First Flight to Land next Year." The Economic Times, November 22. Retrieved November 9, 2020 (https://economictimes.indiatimes.com/news/politics-and-nation/yogis-ayodhya-plans-ashabri-garden-ashok-vatika-ram-setu-and-first-flight-to-land-next-year/articleshow/ 72178685.cms).

Simpson, Edward and Stuart Corbridge. 2006. "The Geography of Things That May Become Memories: The 2001 Earthquake in Kachchh-Gujarat and the Politics of Rehabilitation in the Prememorial era." Annals of the Association of American Geographers 96(3):566-85.

Sircar, Jawhar. 2019. "Why the BJP Feels It has to Appropriate Sardar Patel." The Wire, October 31. Retrieved November 9, 2020 (https://thewire.in/history/bjp-sardar-vallabhbhai-patel).

Speziale, Fabrizio and Audrey Truschke. 2019. "Rediscovering Forgotten Indo-Persian Works on Hindu-Muslim Encounters.” The Wire, May 12. Retrieved November 9, 2020 (https://thewire.in/ history/india-persia-manuscripts-hindu-muslim).

Srivastava, Sanjay. 2011. "Urban Spaces, Disney-divinity and the Moral Middle Classes in Delhi." Pp. 364-90 in Elite and Every Man. The Cultural Politics of the Indian Middle Classes, edited by A. Baviskar and R. Ray. Delhi: Routledge.

Swamy, Rohini. 2020. "Private Trust in Karnataka to Erect 215m Statue of Hanuman in Hampi at Cost of Rs 1,200 cr.” The Print, August 6. Retrieved November 9, 2020 (https://theprint.in/india/ private-trust-in-karnataka-to-erect-215-m-statue-of-hanuman-in-hampi-at-cost-of-rs-1200-cr/ $476164 /$ ).

Talbot, Cynthia. 2016. The Last Hindu Emperor. Prithviraj Chauhan and the Indian Past, 1200-2000. Cambridge: Cambridge University Press.

Tere, Tushar. 2019. "Seaplane for Statue of Unity to Cost Hundreds of Crocodiles their Homes." The Times of India, January 25. Retrieved November 9, 2020 (https://timesofindia.indiatimes.com/ city/vadodara/seaplane-for-statue-of-unity-to-cost-hundreds-of-crocodiles-their-home/ articleshow/67688159.cms). 
The Hindu Staff. 2014. “India's tallest Hanuman statue to be ready by May 2015.” The Hindu, January 2. Retrieved November 9, 2020 (https://www.thehindu.com/news/national/andhrapradesh/indias-tallest-hanuman-statue-to-be-ready-by-may-2015/article5529673.ece).

Tratnjek, Bénédicte. 2012. "Mémoricides dans les espaces post-yougoslaves: de la destruction de la mémoire à la ré-écriture d'une mémoire excluante.” Pp. 215-38 in Guerre, mémoire, identité, edited by G. Cattanéo. Paris: Nuvis.

Tripathi, Purnima. 2020. “Over to Kashi." Frontline, March 13. Retrieved November 9, 2020 (https://frontline.thehindu.com/the-nation/communalism/article30912569.ece).

Truschke, Audrey. 2020. "Exclusion, Affect and Violence in the Many Sites of Indian History." Indian Cultural Forum. June 9. Retrieved August 20, 2020 (https://indianculturalforum.in/ 2020/06/09/exclusion-violence-indian-history-constitution-truschke/).

Venugopal, Vasugha. 2019. "Culture Ministry Charts out Rs 27,000 Crore Plan.” The Economic Times, September 10. Retrieved November 9, 2020 (https://economictimes.indiatimes.com/news/ politics-and-nation/culture-ministry-charts-out-rs-27000-crore-plan/articleshow/

71057588.cms).

\section{NOTES}

1. Full text of the $\mathrm{MoU}$ is available at: https://www.adoptaheritage.in/moupdf/ Red\%20\%20Fort\%20MoU.pdf

2. As part of the Indian numbering system, the terms lakh and crore are widely used as units of money. The former is equivalent to the number 100,000 , the latter to ten million. One lakh roughly corresponds to $€ 1,100$, one crore to $€ 115,000$.

3. See below for an analysis of the program, and http://swadeshdarshan.gov.in/index.php? Theme/themeDetail/7 for details of the circuit.

4. Allahabad was initially known as Prayag (literally, "confluence" in Sanskrit) before being renamed Illahabad (literally, "God's abode" in Persian) by the Mughal emperor Akbar (ruled 1556-1605). As aptly noted by Truschke 2020, the addition of "raj" or "king" to the original Sanskrit name of the city has therefore more to do with present-day fabrication than with resurrection of a supposedly pristine past.

5. For a detailed presentation of the scheme, see the official guidelines available at: http:// swadeshdarshan.gov.in/index.php?page/guidelines. In tourist marketing parlance, "themed routes or tourist circuits connect two or more destinations or products under a unified theme to create a distinct experience for the traveler" (Roy and Gretzel 2020:1).

6. In Savarkar's (1969) conception, Buddhists, Jains and Sikhs also partook of Hindutva (Hinduness) and therefore qualified as Hindus. The term "Hindu" is used accordingly throughout the present essay, while "non-Hindus" refer primarily to Muslims and secondarily to Christians.

7. http://swadeshdarshan.gov.in/index.php?Theme/themeDetail/19

8. The eight sites that I have identified are: Qutb Shahi Heritage Park, Paigah Tombs, Hayat Bakshi Mosque, Nishat Bagh, Shalimar Bagh, Mir Miran Tomb, Sadna Kasai Tomb, Sher Shah Suri Chowk on Srihind Morinda Road.

9. On Jagmohan, see Pati 2014. Nayanjot Lahiri also credits him with removing all the illegal occupation in and around Humayun's tomb in Delhi during the years-long restoration of the Mughal site by the Aga Khan Trust for Culture (Kanga 2017).

10. For two recent detailed presentations and critical appraisals of the scheme, see Sankaran 2019 and Meskell 2020. 
11. https://www.groupefdj.com/fr/mission-patrimoine.html. For other recent European examples of privately funded restorations of national monuments, see Meskell (2020:11).

12. A similar point could be made where the preservation and digitization of manuscripts is concerned. Within the National Mission for Manuscripts established in 2003 under the aegis of the BJP central government, Sanskrit materials take the lion's share whereas Arabic, Persian and Urdu manuscripts are hardly acknowledged. By way of example, the latter represent only $5 \%$ (9 manuscripts) of the forty-five manuscripts promoted as "Treasures of India" by that same mission: https://www.namami.gov.in/treasures-india. For a telling description of the travails awaiting scholars eager to work on Indo-Persian manuscripts preserved in Indian collections, see also Speziale and Truschke 2019.

13. Even though these contemporary creations are of course not historical relicts, I consider them as "heritage artifacts" for at least three reasons: they materially embody (governmental) discourses about the past, house facilities for the public dissemination of these discourses (for many of them) and are meant to accordingly reshape the perception of the past and, in the longer run, the writing of history.

14. While writing these lines, I became aware of Kajri Jain's work on the recent statuary fever and her in-depth analysis thereof. See e.g. Jain 2018 and her forthcoming Gods in the Time of Democracy (Duke University Press 2021). Lack of time has unfortunately prevented me from including other significant examples here.

15. The other six identified colossal effigies are as follows in chronological order of their conception: 1) Hanuman statue at Paritala Anjaneya temple (Andhra Pradesh, 155 feet), completed in 2003 (https://en.wikipedia.org/wiki/Paritala_Anjaneya_Temple); 2) Hanuman statue at Karol Bagh (108 feet, Delhi), completed in 2005 (Pati 2019); 3) Hanuman statue at Madapam (Andra Pradesh, 176 feet), in progress since 2005 (The Hindu Staff 2014); 4) Hanuman statue at Shimla (Himachal Pradesh, 108 feet), completed in 2010 (Bhatt 2010); 5) statue of Shiva as Adiyogi at the Coimbatore Isha Yoga Center (Tamil Nadu, 112 feet), completed in 2017 (Scroll.in Staff 2017); 6) statue of Ramanuja (an eleventh-century Hindu thinker known for advocating Vaishnava bhakti) at Hyderabad (Telengana, 216 feet), completed in 2018 (https:// statueofequality.org/).

16. Source: https://www.indiabudget.gov.in/doc/eb/sbe17.xlsx. In September 2019, the Ministry of Culture submitted a Rs. 27,000 crores five-year plan for developing India's "cultural capital," a quarter of which was supposed to be kept aside for the ASI, thus increasing its budget to Rs 6,769 crores (Venugopal 2019). Whether or not the Fifteenth Finance Commission approved of the plan, it had no impact on the 2020-2021 budget of the ASI nor is any trace of it to be found on its official website (last consulted September 2020).

17. The Shiv Smarak was originally planned in 2004 by the government of Maharashtra, that was led at the time by an Indian Congress-Nationalist Congress Party coalition (1999-2014). When the state passed into the allied hands of the BJP and the right-wing Marathi Shiv Sena in 2014, the project received increased support (the initial Rs 100 crores-budget swelled to 3,800 crores in 2016 before being cut down to 2,500 crores in 2018) and took on a truly pharaonic dimension (Jain 2016).

18. See http://kishkindha.org/statue-of-devotion/ for the official website of the project, and Swamy 2020 for a critical appraisal thereof.

19. In contravention of the "Make in India" initiative launched by N. Modi in 2014 (https:// www.makeinindia.com/home), the bronze cladding and other elements of Patel's statue were produced in a Chinese foundry before being shipped to India (Dave 2018). Such a decision also suggests that the BJP's embrace of neo-liberalism far outweighs its commitment to economic nationalism.

20. On the former, see e.g. the contribution by Audrey Truschke in this volume; and Frykenberg (2008), and Lutgendorf (2007) on the latter. 
21. For in-depth analyses of the complex, see especially Srivastava 2011 and Brosius 2010, with the latter also providing an overview of similarly oriented theme parks in India.

22. http://www.krishnafunland.com/

23. Foremost among these sites are the Ashok Vatika or the garden in Sri Lanka where Sita was held captive by the dev-king Ravana, the Shabri garden where Rama was offered fruit by a tribal woman named Shabri, the Ram Setu or bridge that enabled Rama to cross the Indian Ocean, reach Ravana's kingdom and save Sita from the latter's clutch.

24. It is not clear whether the planned International Ram Katha museum will be a revamped version of the eponymous institution already existing in Ayodhya or an entirely new structure.

25. See e.g. Khanna 2018 and Tere 2019 on Patel's statue; and Chatterjee 2019 on the planned Shiv Smarak.

26. See Arnimesh 2020, and https://www.patrika.com/ayodhya-news/construction-of-eyetheme-park-spa-in-ayodhya-banned-5620778/.

27. First coined in 1985 by Reynald Secher, a French historian of the early modern guerre de Vendée, the term memoricide gained wider currency in relation to the Yugoslav wars (1991-2001). Following the definition by Tratnjek 2012, memoricide here refers to the destruction of any spatial trace of memory, i.e. sites and places infused with a memory symbolism that impacts the way people inhabit and imagine these spaces.

28. It was completed in 1528 on the orders of one of Babur's commandants, not the emperor himself.

29. Decreed in the heat of the Babri Masjid-Ram Janmabhumi dispute, the special provisions of the act "prohibit conversion of any place of worship and (...) provide for the maintenance of the religious character of any place of worship as it existed on August 15, 1947" (http:// legislative.gov.in/sites/default/files/

The\%20Places\%20of\%20Worship\%20\%28Special\%20Provisions\%29\%20Act\%2C\%201991.pdf).

30. See Sayyid 2018 for an insightful survey of the multiple legends surrounding the figure of Baba Budan and the decades-long controversy over the eponymous shrine. For an introduction to the history of the Gyanvapi and the Shahi Idgah mosques that were built during the rule of the Mughal emperor Aurangzeb (r. 1658-1707) on the sites of former temples (dedicated to Shiva and Krishna respectively) which he had had destroyed, see Eaton 2000 who provides a seminal reconsideration of temple desecration by Indo-Muslim rulers.

31. For wide-ranging reflections on names in the context of early modern and contemporary South Asia, see the contributions gathered in Copeman and Das (ed.) 2015.

32. Agra's Hinduization seems to have begun in the early 2000s with the installation of "several traffic roundabouts, all of which were decorated with large statues of either Rajput or Maratha warriors atop horses, brandishing weapons of military might" (Rajagopalan 2011:266).

\section{ABSTRACTS}

The present essay explores three inseparable facets of the BJP's heritage ideology and practices: the state's reluctance to fulfil its traditional role of guardian of the nation's built landscape and the concomitant resort to neoliberal outsourcing strategies to fill in the gap, combined with a strong sectarian bias at work in the shrinking state-sponsored projects of patrimonial management; a strong appetite for building new and exorbitant heritage artefacts; finally, the 
gradual obliteration of all material traces related to the plurisecular presence of Muslims in the subcontinent through physical elimination or renaming, resulting in the growing Hinduization of India's public space.

INDEX

Keywords: Sangh Parivar, BJP, Hindu nationalism, Hindutva, neoliberalism, heritage, patrimony, statuary, renaming, memoricide, Indo-Muslim architecture, Mughal empire

\section{AUTHOR}

CORINNE LEFÈVRE

CEIAS, CNRS-EHESS 